TITLE:

Separation and Identification of Chlorocomplexes of Technetium (IV) formed in Hydrochloric Acid Solutions( Abstract_要 旨)

$\operatorname{AUTHOR}(\mathrm{S})$ :

Kanchiku, Yoshihiko

\title{
CITATION:
}

Kanchiku, Yoshihiko. Separation and Identification of Chlorocomplexes of Technetium (IV) formed in Hydrochloric Acid Solutions. 京都大学, 1970, 理学博士

ISSUE DATE:

1970-01-23

URL:

http://hdl.handle.net/2433/213314

RIGHT: 


\section{【 $82 】$}

氏 名

学位の種類

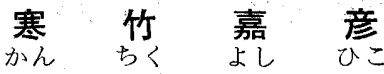

学位記番号

理 学 博士

学位授与の日付

論 理 博 第 297 号

学位授与の要件

昭 和 45 年 1 月 23 日

学位論文題目

学位規則第 5 条第 2 項該当

Separation and Identification of Chlorocomplexes of Technetium (IV) formed in Hydrochloric Acid Solutions

（塩酸溶液中に生成するテクネチウム(IV)クロロ錯体の分離と同定）

論文調查委員嘋授藤永太一郎, 教授重松恒信教授波多野博行

\section{論 交内容の要 旨}

テクネチウムは原子番号 43 番の, 天然には殆んど産出しないと考えられている元素であるが，人工的に 合成された ${ }^{92} \mathrm{TC}$ 加ら ${ }^{100 \mathrm{TC}}$ まで21種の㤥種が知られている。それらのうち最も早く発見された ${ }^{95 m} \mathrm{Tc}$ は 比較的半減期が長く，60日であってエネルギーの大きい $\gamma$ 線を放射する。また ${ }^{97 m} \mathrm{Tc}$ は ${ }^{97} \mathrm{Tc}$ に壊变し， これは K電子捕獲性であって，2.6×106年という長い半隇期をむっている。 ${ }^{95 m} \mathrm{Tc},{ }^{97 m} \mathrm{Tc}$ はいずれもモり ブデンを重陽子で衝撃して得られる。また ${ }^{99} T \mathrm{C}$ はウランの核分裂によって生成する核種の一つであるが $2.12 \times 10^{5}$ 年の半減期をむって $\beta$ 壊変し, 多量に入手し得るのでマク口量の化学的研究に使用するととが できる。

申請者寒竹嘉彦は主論文および参考論文の一部においてテクネチウムの研究を行なっているが，いずれ も上記三種の放射性核種を必要に応じて使い分けている。すなわち主諭文においては過テクネチウム酸ア ンモニウム $\mathrm{NH}_{4}{ }^{99} \mathrm{TCO}_{4}$ を出発物質とし，乙れを塩化カリウムと塩酸によって還元として $\mathrm{K}_{2} \mathrm{TcCl}_{6}$ を生 成させたのち種々の濃度の埧酸に溶解しその吸収スペクトルを测定している。その結果，溶解する酸の濃 度と光の強度によって異なる各種のクロロ錯体の平衡を示す種々の吸収スペクトルを得ており，またての 平衡に達した溶液についてイオン交換法によって四種のクロロテクネチウム錯体を分離すると共に，夫々 の錯体について吸収スペクトルおよび $\mathrm{Tc}: \mathrm{Cl}$ の組成比之電荷を測定して同定を行なっている。

多ず， $\mathrm{K}_{2} \mathrm{TcCl}_{6}$ を $12 \mathrm{M}$ ないし $1 \mathrm{M}$ の塩酸に溶解する之 $12 \mathrm{M}$ 塩酸溶液の吸収スペクトルは变化しない が8M以下の塩酸濃度では光照射によってその吸収スペクトルが変化するとと，然し $12 \mathrm{M} な い ~ 3 \mathrm{M} \mathrm{の}$ 間の塩酸溶液の吸収スペクトルは $310 m \mu$ 之 $362 m \mu$ に等吸収点があり, 分子吸光係数は夫々 6,000 および 3,500であるとと，従ってての波長を利用してテクネチウムの吸光分析を行なうととができるとと，を見 出している。ついで $8 \mathrm{M}$ ないし $1 \mathrm{M}$ の各種塩酸懐度の溶液からイオン交換樹脂を用いて $\left[\mathrm{TCCl}_{6}\right]^{2}$ 以外 の三種のテクネチウムクロロ錯体を分離しており，その夫々について錯体の電荷をイオン交換平衡から求 めるとともに，電荷一1 の錯体については実際に TcとCl の定量を行なってその組成を決定している。そ 
の結果，乙れらの錯体は次に示すような化学形と吸収スペクトル特性を有するととを見出している。

極大吸収波長 分子吸光係数

$\begin{array}{llr}{\left[\mathrm{TcCl}_{5}\left(\mathrm{H}_{2} \mathrm{O}\right)\right]^{1-}} & 235 m \mu & 19,200 \\ {\left[\mathrm{TcCl}_{4}\left(\mathrm{H}_{2} \mathrm{O}\right)_{2}\right]^{0}} & 354 m \mu & 5,500 \\ {\left[\mathrm{TcCl}_{3}\left(\mathrm{H}_{2} \mathrm{O}\right)_{3}\right]^{1+}} & 342 m \mu & -\end{array}$

な扮別に電気泳動法によって上記四種のクロロ錯体の分離を試み，上記の結論を裏付ける， $-2,-1,0$, +1, の電荷を有する化学種の泳動パターンを得ている。

以上の実験によって，塩酸溶液中にお打る光による吸収スペクトルの変化は，次式に示すような逐次加 水反応に基づくものと結論している。

$$
\mathrm{TcCl}_{6}{ }^{2-}+\mathrm{XH}_{2} \mathrm{O} \rightleftharpoons \mathrm{TcCl}_{6-\mathbf{x}}\left(\mathrm{H}_{2} \mathrm{O}\right){ }_{\mathbf{x}}^{(2-\mathbf{x})-}+\mathrm{XCl}^{-}
$$

なお参考論文その一，その二はヂチゾン抽出によって海草中の亜鉛，銅，鉛などの分離濃縮を行なったの ちポーラログラフ分析法を適用して，海洋生物に関する新しい知見を得たものであり，その三からその九 までは放射化学に関する研究である。すなわちその三ではカドミニウムに $37 \mathrm{Mev}$ までの種々のエネルギ 一の陽子衝撃を行なった場合の反応の励起関数を求めたあのであり，その四はテトラシアノニッケルカリ ウムのホットアトム効果に関する研究，その五はテクネチウムの蒸溜，その六，その七はその分光光度定 量, その八，その九は同ク口ロ錯体の光加水反応に関する吥㚾であって，いずれ屯主論文の研究に密接に 関連している。

\section{論 交審 查の 結 果の要旨}

原子番号43番のテクネチゥムは天然に産出しないので専ら人工的に合成された核種によって，その化学 的性質が検討されており，その原子価状態としては＋7からー1まですべての段階が存在し得ることが知 られている。しかし多くの化学的研觉は最す安定な+7 佂の過テクネチウム酸に関するものであって，よ り金属的な低原子価状態の化合物についての研究はあまり行なわれていない。

申請者寒竹嘉彦はかねて +4 価のテクネチゥムのクロロ錯体に注目し，ての錯体が浱塩酸溶液中では安 定であるが希塩酸中において光化学的に活性であることを見出していたが特に主論文の研究に执いて，こ の[ $\left.\mathrm{TCCl}_{6}\right]^{2-}$ の光化学反応が置換反応であることを示すとともにその反応によって生成する新しい水和ク ロロ錯体の分離と同定を行なって，本元素の物性を一段之明らかにしたものである。

すなわち本研究においては出発物質である過テクネチウム酸アンモニウム $\mathrm{NH}_{4}{ }^{9}{ }^{9} \mathrm{TCO}_{4}$ を塩化カリウム と塩酸によって還元して $\mathrm{K}_{2} \mathrm{TCCl}_{6}$ を生成さ甘，乙れを種々の濃度の塩酸に溶解して，それらの吸収スペ クトルを測定しているが，その際吸収スペクトルは光の強度と塩酸の濃度に依存して，ある平衡に達する ことを見出して扣り，更にての平衡混合溶液からイオン交換法によって四種のテクネチウム錯体を分離 し，夫々について錯化学的ならびに分光化学的に貴重な知見を得ている。

まず $\mathrm{K}_{2} \mathrm{TcCl}_{6}$ を各種濃度の塩酸に溶解すると，12M 塩酸については吸収スペクトルが変化しないが， $8 \mathrm{M}$ ないし $1 \mathrm{M}$ の間の塩酸ではその吸収スペクトルが変化するととを見ている。

しかし一方，12M から $3 \mathrm{M}$ の間の塩酸溶液の吸収スペクトルは $311 m \mu と 362 m \mu$ につの等吸収点を 
示し，てれによって踏体の種類組成に関係なくテクネチウムの吸光分析を行ない得ることを明らかにして いる。

またイオン交換法を巧みに応用して $\left[\mathrm{TCCl}_{6}\right]^{2-}$ の他に三種のテクネチウム錯体を単離し，夫々について イオン交換平衡から電荷を算定するとともに，それらが次のような吸収スペクトル特性を示す錯体である ととを明らかにしている。

$\begin{array}{ccc} & \text { 極大吸収波長 } & \text { 分子吸光係数 } \\ {\left[\mathrm{TCCl}_{5}\left(\mathrm{H}_{2} \mathrm{O}\right)\right]^{--}} & 235 m \mu & 19,200 \\ {\left[\mathrm{TcCl}_{4}\left(\mathrm{H}_{2} \mathrm{O}\right)_{2}\right]^{0}} & 354 m \mu & 5,500 \\ {\left[\mathrm{TcCl}_{3}\left(\mathrm{H}_{2} \mathrm{O}\right)_{3}\right]^{+}} & 342 m \mu & -\end{array}$

なおまた電気泳動法による泳動パターンからあ上記四種の錯体に相当する $-2,-1,0,+1$ の電荷を有す る化学種を確認し，四価テクネチウムのクロロ錯体の光による吸収スペクトルの変化は次式に示すような 〔 $\left.\mathrm{TCCl}_{6}\right]^{2-}$ の逐次加水反応であることを明らかにしている。

$$
\mathrm{TcCl}_{6}{ }^{2-}+\mathrm{xH}_{2} \mathrm{O} \rightleftharpoons \mathrm{TcCl}_{6-\mathrm{x}}\left(\mathrm{H}_{2} \mathrm{O}\right) \mathrm{x}^{(2-\mathbf{x})-}+\mathrm{xCl}^{-}
$$

また参若論文九篇のうち二篇は溶媒抽出ポーラグラフ分析法を検討して海草中の微量成分分析に応用し たすのであり，他の七篇は放射化学ないし核化学における貴重な知見を得た研究であって，特にうち二篇 はテクネチウムの光化学反㣽関するものであって主論文の研究に密接に関連している。

要するに申請者寒竹嘉彦は人工元素であるテクネチウムの四価の原子価状態におけるクロロ錯体をとり 上げ，この光化学反応に着目してその反応機構を明ら加にするとともに逐次生成する各種の加水錯体の物 性を明らかにしたあのであって，関連した分野に寄与するとてろが少なくない。

また主論文参考論文を通じて豊富な知識执よび優れた研究能力をもっているととを認めるととができ る。

よって本論文は理学博士の学位論文として価值があるあのと認める。 